\title{
Ocorrência da ferrugem da videira em Roraima
}

Bernardo de Almeida Halfeld-Vieira, Kátia de Lima Nechet, Rosianne Nara Thomé Barbosa

Embrapa Roraima, BR 174, km 8, Distrito Industrial, CP 133, 69301-970, Boa Vista-RR.

Autor para correspondência: Bernardo A. Halfeld-Vieira (halfeld @ cpafrr.embrapa.br)

Data de chegada: 30/07/2008. Aceito para publicação em: 15/06/2009.

A cultura da videira (Vitis spp.) vem sendo implantada em Roraima, atualmente abrangendo uma área de aproximadamente 40 ha. Com a expansão dos cultivos e a introdução de material propagativo de outras regiões do país, aumentam os riscos da introdução de patógenos que causam grandes danos à cultura. Um exemplo é a introdução da bactéria Xanthomonas campestris pv. viticola, patógeno quarentenário presente no Estado, introduzido por meio de propágulos vegetativos provenientes de Petrolina, PE (Halfeld-Vieira B.A., Nechet K.L. Fitopatologia Brasileira, v.31, p.604, 2006). Em junho de 2008, em análise de material de videira cv. Niágara rosada, proveniente de área de cultivo em Boa Vista, RR, foram constatados sintomas de ferrugem, em plantio estabelecido por meio de propágulos oriundos do Rio Grande do Sul. Em análises em microscopia foram verificadas as seguintes características do fungo associado: urédios hipófilos, com paráfises cilíndricas, subepidérmicos e irrompentes, urediniósporos globóides, 24-26 x 15-18 $\mu \mathrm{m}$; teliósporos dispostos em 3 camadas, oblongos, 24-28 x $10 \mu \mathrm{m}$. Estas características permitiram identificar Phakopsora euvitis Ono como o agente causal da ferrugem da videira em Roraima (Ono, Mycologia v.92, p.154-173, 2000; Tessmann D.J., Dianese, J.C., Genta, W., Vida, J.B., May-de-Mio, L.L., Fitopatologia Brasileira v.29, p.338. 2004).

Para realização de testes de patogenicidade, foi preparada uma suspensão de urediniósporos coletados de folhas de plantas da cv. Niágara rosada, que apresentavam pústulas da ferrugem em campo, ajustando-se a concentração a $10^{3}$ esporos. $\mathrm{ml}^{-1}$. Plantas de videira desta mesma cultivar foram inoculadas por pulverização da suspensão de urediniósporos, mantendo-se em câmara úmida por $24 \mathrm{~h}$ e, posteriormente, em condições de casa de vegetação. Aos 12 dias após a inoculação foram observadas pústulas nas plantas inoculadas.

A ferrugem da videira teve sua ocorrência registrada pela primeira vez em maio de 2001 no estado do Paraná e atualmente o patógeno está com constatação descrita em Mato Grosso, Mato Grosso do Sul, Pernambuco, Rio de Janeiro, Rio Grande do Sul e São Paulo. Sua disseminação ocorre à longa distância por meio de propágulos infectados e, em condições de campo, pelo vento. Atualmente, a doença se encontra restrita em plantios realizados na cidade de Boa Vista. Este é o primeiro relato da doença no estado de Roraima.

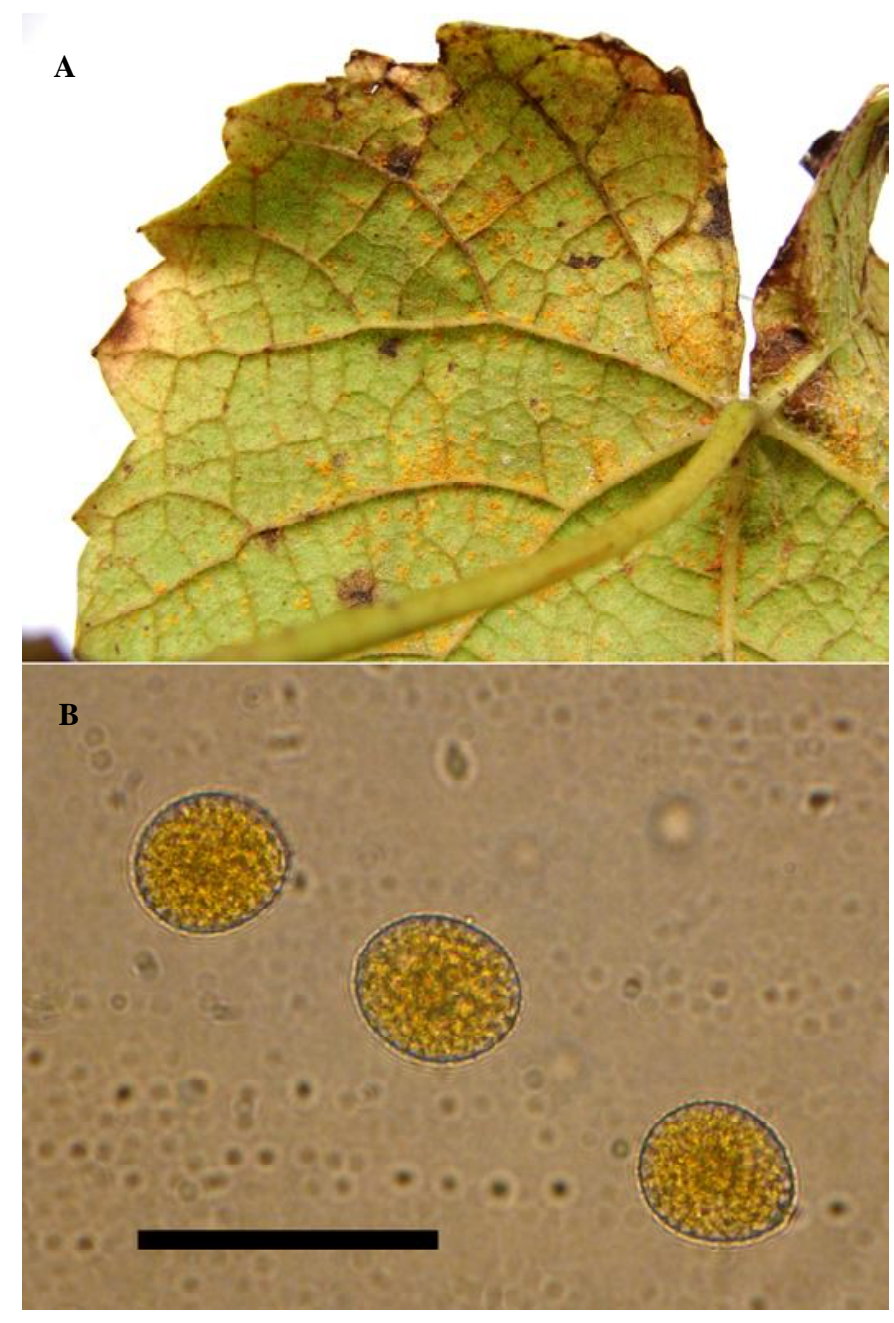

Figura 1. Sintomas e sinais da ferrugem da videira (A); urediniósporos de Phakopsora euvitis (B) (barra $=40 \mu \mathrm{m})$. 